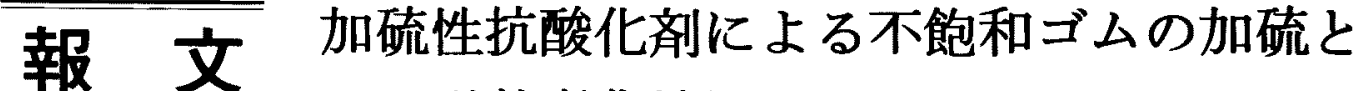 その耐熱老化性 ${ }^{\dagger}$
}

(昭和58年 8 月 1 日 受理)

森 邦夫*·常石牧子*·中村儀郎*

\begin{abstract}
要旨 2-抗酸化性基-4,6-ビス(4-モルホリニルトリチオ)1,3,5-トリアジンによるIR, BR, SBR 及び EPDM などの不飽和ゴムの加硫性, 抗酸化性基の結合性, 加硫鎖構造及ひ耐熱老化性などについて梌討し た. 加硫性抗酸化郕は酸化亜鉛とステアリン酸の共存下で加硫剤として作用し，その反応性はゴムの種類の 影響を受けた. TMTM, CBS 及びMBTSなどの加硫促進郕の併用は加硫速度と加硫度(トルク)の增加に有 効であった，抗酸化性基の結合率は BR, SBR で高く，IR， EPDM で低かった，CBSや MBTS は結合率を 高めるのに，特に有効な促進剂であった．しかし，これらはモノスルフィド加硫鎖含有量を高めるのに充分 とはいえないが.TMTM はこの点で特に有効であった。加硫性抗酸化剮とTMTMの組み合わせは結合率 とモノスルフィド加硫鎖含量の両方で優れているので, 市眅の抗酸化剤の散逸する高温下や溶剤との接触条 件下で，特に耐熱老化性の加硫物を与えることがわかった。
\end{abstract}

\section{1. 緒言}

最近のゴム製品は，ますます苛酷な条件下で使用され る傾向が強くなってきたため，熱による安定剤の揮散や 水，油などの溶剤による安定剤の溶出がゴム製品の性能 低下や環境污染の原因となり，大きな問題となってい る.これに対し，加工中にゴム分子と化学的に結合する 反応性抗酸化剤 ${ }^{(\sim 4)}$ ，抗酸化性基を有するモノマーの共 重合体ゴム ${ }^{5 \sim 9)}$ ，高分子量抗酸化剂 ${ }^{10 \sim 139}$ 及び不溶不融性 抗酸化剂(4)などを用いる方法が提案されている。

著者ら洗先に加硫性，抗酸化性及び非抽出性の三機能 を有する2-抗酸化性基-4,6-ビス(4-モルホリニルポリチ オ）1,3,5-トリアジンを合成し，これらによるNBR の加 硫反応性，抗酸化性基の結合率及びこれらの抗酸化性基 が結合した NBR 加硫物の耐熱老化性，耐複合劣化性及 び耐サワーガソリン性などについて報告した1516)．

本報ではこれに引き続き，不飽和ゴムの種類と2-抗酸 化性基-4,6-ビス(4-モルホルニルトリチオ)1,3,5-トリ アジンの加硫性, 結合性, 加硫鎖構造及ひ耐熱老化性な どの関保について述べる。

†本報を「多機能性涯加剂に関する研究 第 8 報」とす る.

* 岩手大学工学部応用化学科 ( T020 岩手県盛岡市上田 4-3-5)
2. 実

験

\section{1 材料と試㩰}

ポリイソプレン(IR；JSR IR2200)，ポリブタジエン （BR; JSR BR01），スチレンーブタジェン共重合体 (SBR; JSR1500)，エチレン-プロピレン-エチリデン） ルボルネン三元共重合体(EPDM；JSR EP24)などの合 成ゴムは市販品を使用した。

加硫性抗酸化剂は前報に従って合成し15)，次の $\mathrm{AD}$ 3SM と 3C-3SM の二種を使用した。

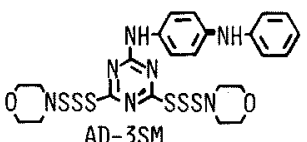

AD-3SM

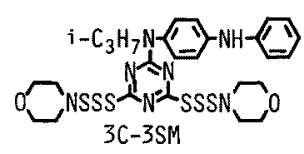

TMTM, TMTD, CBS及びMBTS などの加硫促進剤, 酸化重鉛( \#1 号)及びステアリン酸などの添加剤も市服 品をそのまま使用した。

\section{2 配合と加硫}

基本配合とコントロール配合を Table 1 に示す。これ らのゴムと添加剂を $50^{\circ} \mathrm{C}, 10$ 分間ロール上で混合, ブ レンドしてゴムコンパウンドとし，これらの加硫曲線は オシレーティングディスクレオメータ(東洋精機而型)に より測定し，加硫速度定数 $\left(\mathrm{k}, \mathrm{min}^{-1}\right)$ と誘導期 $\left(\mathrm{t}_{0}, \mathrm{~min}\right)$ を求めた。 また，加硫物試料は上記ゴムコンパウンドを $140^{\circ} \mathrm{C}$ 又は $160^{\circ} \mathrm{C} て ゙ 30$ 分又は 60 分間熱プレスして得た.

\section{3 結合事とモノスルフィド加硫銷合量}


抗酸化性基の結合率は Table 1 の配合表からカーボン ブラックを除いた配合㘊をゴムと混合，ブレンド偻熱プ レスして得た加硫試料について，下記の処法で決定し た。 すなわち，試料 $(40 \times 10 \times 1 \mathrm{~mm}, 3$ 枚およて $1 \mathrm{~g})$ を 酶酸ーテトラヒドロフラン溶液 $5 \%) に 60^{\circ} \mathrm{C} ， 24$ 時間浸 清後, アセトンークロロホルムーメタノール共沸溶剂35： $29: 28 \mathrm{v} / \mathrm{v})$ でソックスレー抽出を行い, 加硫試料加ら 結合していない添加剤をすべて除去した，次にこれらの 試料の安素含量をケルダール法により求め, 抗酸化性基 の結合样式を次の加硫鎖構造で示される ${ }^{15)}$ と仮定して，

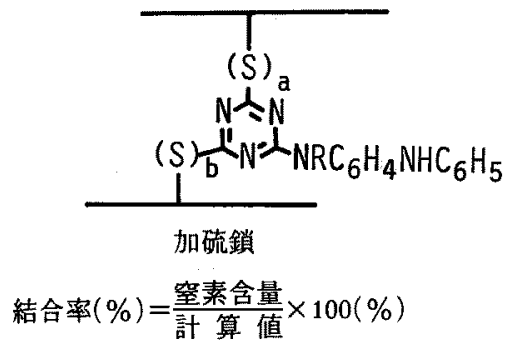

100\%結合時の窒素含量を計算し，式(1)加ら抗酸化性基 の結合率を求めた。

一方，モノスルフィド加硫鎖含量(MS)は上記の加硫

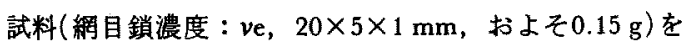

Table 1 Base and control recipes

\begin{tabular}{|c|c|c|c|}
\hline \multicolumn{2}{|l|}{ Base Recipes } & \multicolumn{2}{|c|}{ Control Recipes ${ }^{c}$} \\
\hline Rubbers ${ }^{\text {a }}$ & 100 parts & Rubbers $^{\text {a) }}$ & 100 parts \\
\hline HAF Black & $50 \mathrm{phr}$ & HAF Black & $50 \mathrm{phr}$ \\
\hline $\begin{array}{l}\text { Vulcanizing } \\
\text { antioxidants }\end{array}$ & $4.8 \mathrm{mmol}$ & $\begin{array}{l}\text { TMTM } \\
\text { CBS }\end{array}$ & $\begin{array}{l}1.5 \mathrm{phr} \\
1.5 \mathrm{phr}\end{array}$ \\
\hline Accelerators ${ }^{b)}$ & $4.8 \mathrm{mmol}$ & $\mathrm{s}$ & $0.5 \mathrm{phr}$ \\
\hline $\mathrm{ZnO}$ & $5 \mathrm{phr}$ & $\mathrm{ZnO}$ & $5 \mathrm{phr}$ \\
\hline Stearic Acid & $1 \mathrm{phr}$ & $\begin{array}{l}\text { Stearic acid } \\
\text { IPPD }\end{array}$ & $\begin{array}{l}1 \mathrm{phr} \\
1 \mathrm{phr}\end{array}$ \\
\hline
\end{tabular}

a) IR, BR, SBR, EPDM.

b) TMTM, CBS, MBTS.

c) EPDM control recipes: EPDM 100 parts, HAF black $50 \mathrm{phr}$, Oil $30 \mathrm{phr}$, CBS $3 \mathrm{phr}$, TMTM 0.75 phr, ZnBDC $1.5 \mathrm{phr}$, S $0.5 \mathrm{phr}, \mathrm{ZnO} 5 \mathrm{phr}$, Stearic acid 1 phr, IPPD 1 phr.

チオフェノールートルエン溶液 $(2 \%) 20 \mathrm{~m} l$ 中で $60^{\circ} \mathrm{C} 48$ 時間漫せきし，還元後の網目鎖濃度 $\left(v_{\mathrm{e}}^{\prime}\right)$ を Flory-Rehner の式を用いて決定し(7) 19)，式(2)からモノスルフィド加 硫鎖含量を求めた.

$$
M S(\%)=\frac{\nu_{\mathrm{e}}}{\boldsymbol{v}_{\mathrm{e}}^{\prime}} \times 100
$$

\section{4 熱老化試嬐}

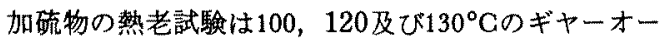
ブン中で行い，島津オートクラプ S-100kより，老化前 後の試料の強度と伸度 $\left(20^{\circ} \mathrm{C}\right.$ で $200 \mathrm{~mm} / \mathrm{min}$ の引張速 度）を測定し，これから老化後の保持率を求め，老化の 程度を評価した。

\section{3. 結果と考察}

\section{1 加硫性}

加硫性抗酸化剂. AD-3SM と 3C-3SM による不飽和 ゴムの加硫反応が奏用的レベルで進行するためには酸化 亜鉛とステアリン酸の共存が必要である.才なわち，

Fig. 1 に AD-3SM による BR の加硫反応における必須 成分走したが，AD-3SM，酸化亚鉛及びステアリン 酸の三成分が共存して初めて奏用レベルの加硫物が得ら れ，これらのうち一成分加欠けても加硫反心は充分に進 行しなくなる，また，これらが必須成分であることは BR 以外のIR, SBR, EPDM についても同様であった。

Fig. 2 には加硫反応性に及ぼすゴムの種類と加硫性抗 酸化剂の種類の影響を示す.コントロール配合における 反応性の違いはゴムの種類ではほとんど認められない が, AD-3SM と 3C-3SM による加硫についてはゴムの 種類の影響が顕著に認められる。すなわち，AD-3SM

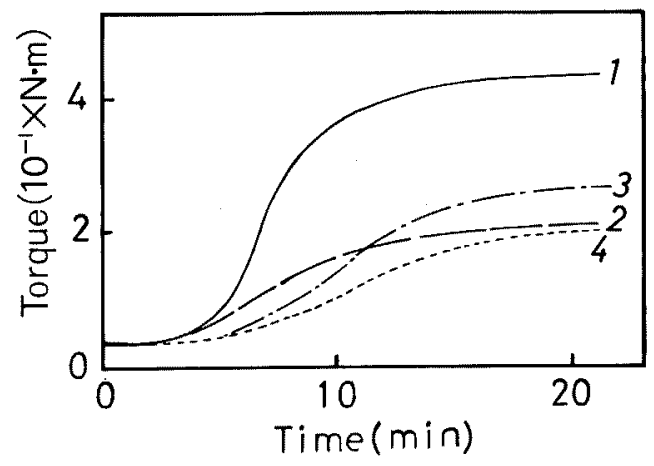

Fig. 1 Essential component of the vulcaniation of BR with $\mathrm{AD}-3 \mathrm{SM}$ at $160^{\circ} \mathrm{C}$.

\begin{tabular}{|c|c|c|c|c|}
\hline & 1 & 2 & 3 & 4 \\
\hline AD-3SM (phr) & 3 & 3 & 3 & 3 \\
\hline $\mathrm{ZnO}(\mathrm{phr})$ & 5 & - & 5 & - \\
\hline St. A (phr) & 1 & 1 & - & - \\
\hline$k\left(\min ^{-1}\right)$ & 0.38 & 0.17 & 0.27 & 0.12 \\
\hline$t_{0}(\min )$ & 5.4 & 4.1 & 8.0 & 5.9 \\
\hline
\end{tabular}




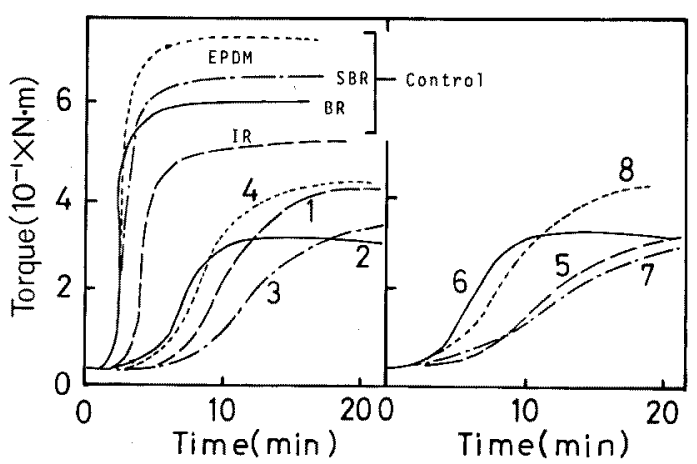

Fig. 2. Vulcanization curves of some rubbers with $\mathrm{AD}-3 \mathrm{SM}$ and $3 \mathrm{C}-3 \mathrm{SM}$ at $160^{\circ} \mathrm{C}$.

\begin{tabular}{lcccc}
\hline & \multicolumn{4}{c}{ AD-35M } \\
\cline { 2 - 5 } NO. & 1 & 2 & 3 & 4 \\
\hline Rubbers & IR & BR & SBR & EPDM \\
\hline $\mathbf{k}\left(\min ^{-1}\right)$ & 0.64 & 0.38 & 0.34 & 0.39 \\
$\mathbf{t}_{0}(\min )$ & 4.7 & 5.2 & 8.2 & 6.8 \\
\hline & \multicolumn{5}{c}{$3 \mathrm{C}-3 \mathrm{SM}$} \\
\hline & 5 & 6 & 7 & 8 \\
\hline NO. & IR & $\mathrm{BR}$ & $\mathrm{SBR}$ & $\mathrm{EPDM}$ \\
\hline Rubbers & 0.65 & 0.33 & 0.22 & 0.17 \\
\hline $\mathrm{k}\left(\mathrm{min}^{-1}\right)$ & 6.6 & 5.6 & 9.2 & 8.6 \\
$\mathrm{t}_{0}(\min )$ & \multicolumn{5}{c}{} \\
\hline
\end{tabular}

と3C-3SMは酸化亜鉛とステアリン酸の共存下で IR に 対して非常に高い反応性を示寸. AD-3SM の加硫反応 性は BR，SBR，EPDM などゴムの種類によってほと んど変化しないが，3C-3SM ではゴムの種類による違 いが影著である.この理由は必ずしも明らかでないが， 加硫反応が前報15)で述べたような機構で進行するとすれ ば，加硫剤，加硫前駆体，加硫活性体などのゴムに対す る溶解性やゴム自身の反応点の違いが加硫反応性に関係 したためと考えられる.

Fig. 3 は AD-3SM とTMTM の組み合わせによる加 硫反応をゴムの種類を変えて比較换討したものである. TMTMの共存により加硫速度は一样に堌加し，ゴムの 違いによる加硫性の変化の傾向は Fig. 2 のコントロー ルの場合とほとんど一致し，TMTMの泒加効果が強く 表かれる. TMTM 添加の前捘に抢けるトルクの增加は 絧目鎖濃度とモノスルフィド加硫鎖含量の增加を意味す ると考えられる. このような TMTM の添加効果は 3C-

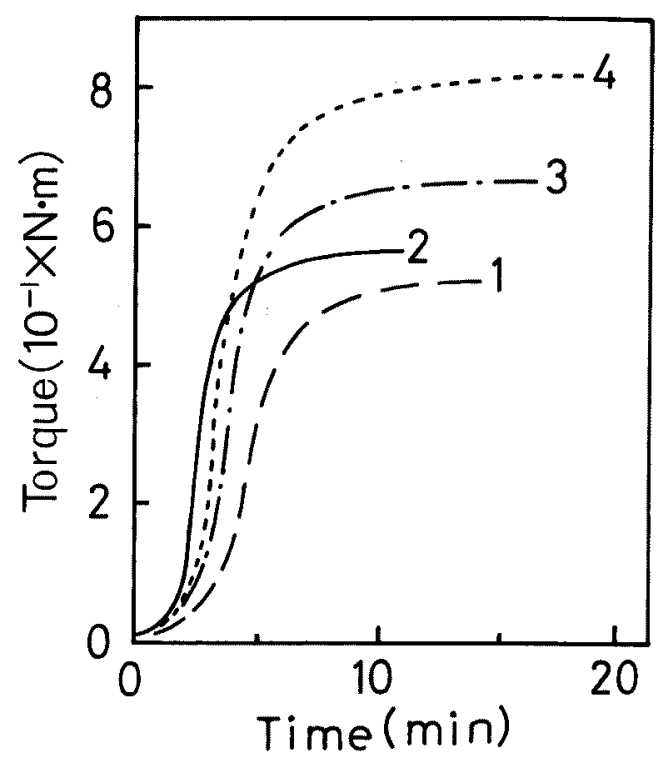

Fig 3 Vulcanization curves of rubbers with $\mathrm{AD}$ $3 S M$ and TMTM at $160^{\circ} \mathrm{C}$.

\begin{tabular}{lcccc}
\hline & 1 & 2 & 3 & 4 \\
\hline Rubbers & IR & BR & SBR & EPDM \\
\hline $\mathrm{k}\left(\min ^{-1}\right)$ & 1.2 & 0.66 & 0.86 & 0.65 \\
$\mathrm{t}_{0}(\min )$ & 2.1 & 2.6 & 3.0 & 3.8 \\
\hline
\end{tabular}

3SMについても同しように認められ，AD-3SM との違 いがなくなる. Fig. 4 4 AD-3SMによる BR の加硫反 応に及ほす加硫促進剤の種類の影響を示す。いずれの促 進剤もAD-3SM との組み合わせで著しく加硫を促進す るが，特にTMTM と CBS で顕著であった，トルクも MBTS $\leqq \mathrm{CBS}<\mathrm{TMTM}$ の順序で大きくなり，この順序 でモノスルフィド加硫鎖含量が增加していることを暗示 している. このような傾向は加硫性抗酸化剂の種類又は ゴムの種類が変わっても同様に認められた。

\section{2 抗酸化性基の結合事}

加硫性抗酸化剤が有効であるための第一の条件は，抗 酸化性基のゴムに対する結合率が充分に高いことであ る. Table 2 に $160^{\circ} \mathrm{C} 30$ 分間プレス加硫後の結合率を示 す.ゴムの種類による結合率の違いは加硫性抗酸化剂と 加硫促進剤の違いによっても異なるが，一般に BR と SBRの結合率が大きく，IR と EPDMのそれは小さい， これはIR と EPDM の反応点の立体障害が BR や SBR のそれより大きいためと考えられる。このような反応点 の立体障害が抗酸化性基の結合率に大きな影響を及佸才 


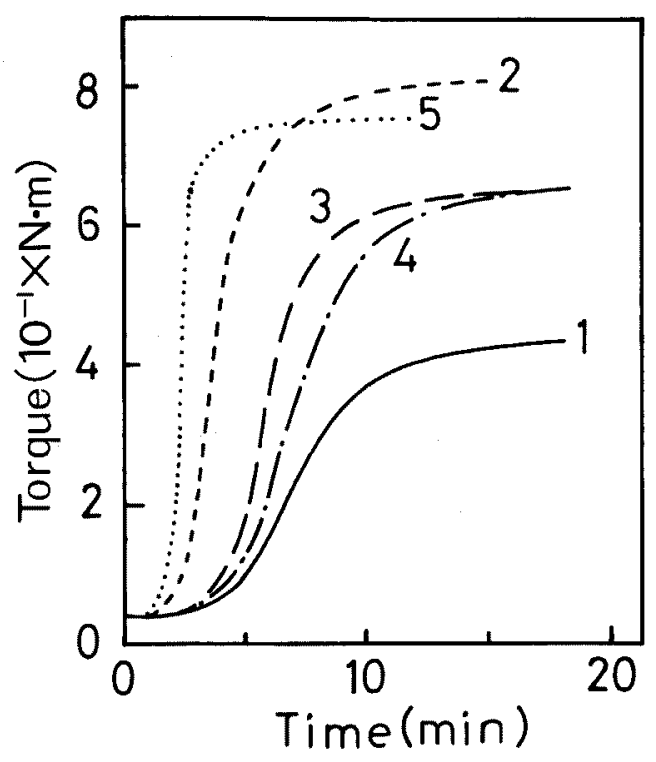

Fig. 4 Vulcanization curves of rubbers with $\mathrm{AD}$ 3SM and $\mathrm{TMTM}$ at $160^{\circ} \mathrm{C}$.

\begin{tabular}{lccccc}
\hline & 1 & 2 & 3 & 4 & 5 \\
\hline Accelerators & - & TMTM & CBS & MBTS & Control \\
\hline $\mathrm{k}\left(\min ^{-1}\right)$ & 0.38 & 0.66 & 0.68 & 0.43 & 1.66 \\
$\mathrm{t}_{0}(\min )$ & 5.2 & 2.6 & 4.8 & 5.2 & 1.9 \\
\hline
\end{tabular}

と考えるのは，加硫性抗酸化放自身がバルキーであるた めである ${ }^{15)}$. 加硫性抗酸化剂の種類による結合率の違い は，BR，SBR とIR，EPDMの場合で翼なる.すなわ ち、BRと SBRにおける結合率は 3C-3SM より AD3SMの方が大きいが，IR と EPDMにおけるそれはこ れと反対である。これは AD-3SM の加硫反応性が高い ということと，3C-3SM のゴムに対する溶解性が大き いという特幑のためであろう。加硫促進剤の添加も結合 率に大きな影響を与えるが，結合率を高める加硫促進剂
とそうでないものがある，一般に TMTMは結合率を減 少させるが，これ泣抗酸化性基を含むポリスルフィド加 硫鎖がTMTMにより脱硫され，一度結合した抗酸化性 基がゴム分子から脱離するためと考えられる. CBS と MBTS は抗酸化性基の結合率を高めるのに有効である が，これは CBSとMBTSが上記のような作用より，脱 硫時に生成した下記のチオール基をもつ不活珄化合物を SS 基に変えて活性化させ，ゴム分子と再度結合させるこ

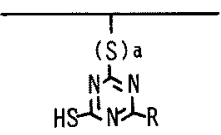

不活性化合物

とのできる作用を強く発揮するためである20/21). IR と EPDM の加硫反応では抗酸化性基を有する加硫活性体 が立体障害のため反応しにくく失活して不活性化合物と なり，脱硫により生成した抗酸化性基の含まれない加硫 活性体によって加硫される傾向が強い，結果として， IR と EPDM の結合率は全般に低い。しかし，CBSや MBTS の添加量を多くすると結合率を高めることがで きるし，また，IRの AD-3SM とTMTMによる加硫の

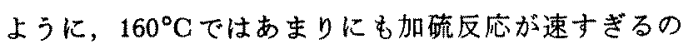
で, $140^{\circ} \mathrm{C}$ と比較的低温で加硫を行うと，結合率は $24 \%$ から40\%と改良されることが明らかとなった.これは加 硫があまりにも早すぎると，加硫促進㓮が加硫のみに使 われて消費してしまい，不活性化合物を活性化すること ができなくなってしまうためと考えられる。

\section{3 加䟽鎖棒造}

$\mathrm{AD}-3 \mathrm{SM}$ 又は 3C-3SM から生成する加硫鎖は次のモ ノスルフィド加硫鎖とポリスルフィド加硫鎖からなると

$$
\begin{aligned}
& \text { R } \quad 1 \leqq a \leqq b \leqq 3
\end{aligned}
$$

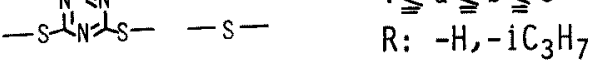

$$
\begin{aligned}
& \text { モノスルフィド加硫鎖 ポリスルフィド加硫鎖 }
\end{aligned}
$$

Table 2 Effects of rubbers and accelerators on the \% bound of antioxidant groups in the $160^{\circ} \mathrm{C} \times 30$ min hot pressed samples.

\begin{tabular}{|c|c|c|c|c|c|c|c|c|}
\hline \multirow{2}{*}{$\begin{array}{c}\text { Vulcanizing antioxidants } \\
\text { Accelerators }\end{array}$} & \multicolumn{4}{|c|}{ AD-3SM } & \multicolumn{4}{|c|}{$3 \mathrm{C}-3 \mathrm{SM}$} \\
\hline & - & TMTM & CBS & MBTS & - & TMTM & CBS & MBTS \\
\hline IR & 39 & 25 & 46 & 42 & 45 & 24 & 49 & 54 \\
\hline BR & 98 & 81 & 99 & 99 & 75 & 81 & 99 & 98 \\
\hline SBR & 82 & 86 & 97 & 98 & 81 & 85 & 85 & 89 \\
\hline EPDM & 21 & 18 & 24 & 45 & 36 & 30 & 52 & 82 \\
\hline
\end{tabular}


Table 3 Monosulfide crosslinkage contents (MS) of the $160^{\circ} \mathrm{C} \times 30 \mathrm{~min}$ hot pressed rubbers.

\begin{tabular}{|c|c|c|c|c|c|c|c|c|}
\hline \multirow[b]{2}{*}{ Rubber } & \multicolumn{4}{|c|}{$A D-3 S M$} & \multicolumn{4}{|c|}{$3 \mathrm{C}-3 \mathrm{SM}$} \\
\hline & - & TMTM & CBS & MBTS & - & TMTM & CBS & MBTS \\
\hline IR & 12 & 40 & 13 & 15 & 0 & 44 & 14 & 16 \\
\hline $\mathrm{BR}$ & 0 & 75 & 42 & 45 & 33 & 42 & 10 & 13 \\
\hline SBR & 26 & 78 & 51 & 60 & 9 & 82 & 45 & 50 \\
\hline EPDM & 11 & 61 & 42 & 41 & 0 & 73 & 52 & 58 \\
\hline
\end{tabular}

考えられる15). 加硫性抗酸化剂の効果を高めるためのむ う一つの因子は，加硫鎖が熱により変化しないモ/スル フィド加硫鎖からなることである. Table 3 はモノスル フィド加硫鎖含量に及ぼす加硫性抗酸化㓮とゴムの種類 の影響を示している. 加硫性抗酸化剤とゴムの種類によ るモノスルフィド加硫鎖含量の違いは認められないが， 加硫促進剤の種類の違いは顕著であり，加硫促進剂が共 存するとモノスルフィド加硫鎖含量は高くなる. 特に TMTM は，MBTS やCBSに比べてすべてのゴムで高 いモノスルフィド加硫鎖含量を与える.また， $\mathrm{AD}-$ 3SM-TMTM 系によるIRの加硫のように，加硫速度の 速い場合は加硫温度を下げると有効であった，例えば， 加硫温度を $160^{\circ} \mathrm{C}$ から $140^{\circ} \mathrm{C} に$ 下げると, モノスルフィ ド加硫鎖含量は $40 \%$ から $75 \%$ に上昇した。

一方，CBSやMBTS は結合率を高めるのに有効であ るが，モノスルフィド加硫鎖含量を高める作用は少な い.しかし，Table 4からわかるように，MBTS を增加 してもモノスルフィド加硫鎖含量の大幅な增加につなが らないが，TMTMとMBTSを併用すると，結合率が 减少することなくモノスルフィド加硫鎖含量を高めるこ とができた。

\section{4 耐熱老化性}

加硫ゴムの涌熱老化性は，添加された抗酸化剂の揮発 や水，油などの溶剂による溶出によって著しく低下する と考えられている。したがって，抗酸化剤がゴムに結合 していればこのような問題も起こらなく，加硫ゴムの耐 熱老化性は長期間にわたって保持されるはずである.

Fig. 5 と 6 K，加硫性抗酸化剂 AD-3SM 又は 3C3SM で加硫した SBR 加硫物について, 抽出前後の試料 の $120^{\circ} \mathrm{C}$ における耐熱老化性を示した。一般に 3C-3SM より $\mathrm{AD}-3 \mathrm{SM}$ のほうが抽出前後の試料上も耐熱老化性 に優れた加硫ゴムを与える. 抗酸化性基の結合した試料 では，熱老化初期において必ずしもコントロール加硫ゴ ムより優れた耐熱老化性が得られないが，一般の抗酸化 剤が揮発する老化後期になると結合した抗酸化剤の効果
Table 4 Combination effect of TMTM and MBTS on the $\%$ bound and MS in the $160^{\circ} \mathrm{C} \times 30 \mathrm{~min}$ hot pressed samples.

\begin{tabular}{lcccc}
\hline & 1 & 2 & 3 & 4 \\
\hline IR & 100 & 100 & 100 & 100 \\
3C-3SM & 3.2 & 3.2 & 3.2 & 3.2 \\
TMTM & 1 & - & - & 1 \\
MBTS & - & 1.6 & 2.5 & 1.6 \\
ZnO & 5 & 5 & 5 & 5 \\
St. A & 1 & 1 & 1 & 1 \\
\hline$\%$ Bound (\%) & 24 & 54 & 66 & 68 \\
\hline MS (\%) & 40 & 13 & 18 & 68 \\
\hline
\end{tabular}

が表われるようになる。一方，加硫試料を溶郕で抽出処 理してゴムと結合しない成分をすべて除去すると，加硫 性抗酸化肪を使用した試料の耐熱老化性はコントロール のそれに比べて著しく高く，抗酸化性基をゴムに結合さ せることがゴムの老化防止に重要であることがわかる. 加硫促進剂の添加は $120^{\circ} \mathrm{C}$ 以上の高温での老化桑件にお いて有効であるが，一般にその効果は抽出前試料におい てはコントロール<MBTS<CBS<TMTM の順序で, また抽出後試料においてはコントロール<MBTS $<$ CBS<TMTM の順序で高くなり，この傾向は一般に抗 酸化性基の結合率とモノスルフィド加硫鎖含量の高くな る順序と一致しており，前述したようにこれら二つの因 子が高温下での老化防止に重要であることがわかる。高 温下での耐熱老化性はゴムと加硫促進肪の違いにより若 干異なるが，Fig. 7 からわかるように BR でも同様の傾 向が認められ，AD-3SM-TMTM 系が最も耐老化性に 優れた加硫ゴムを与えた．また，IRについては上記の 配合で充分な結合率とモノスルフィド加硫鎖含量が得ら れないので，耐熱老化性に優れた加硫ゴムは得られ難 い。しかし，前述したように AD-3SMに TMTM と MBTS を併用すると，結合率とモノスルフィド加硫鎖 含量が高くなるので，IR 加硫物の酎熱老化性は改良さ 


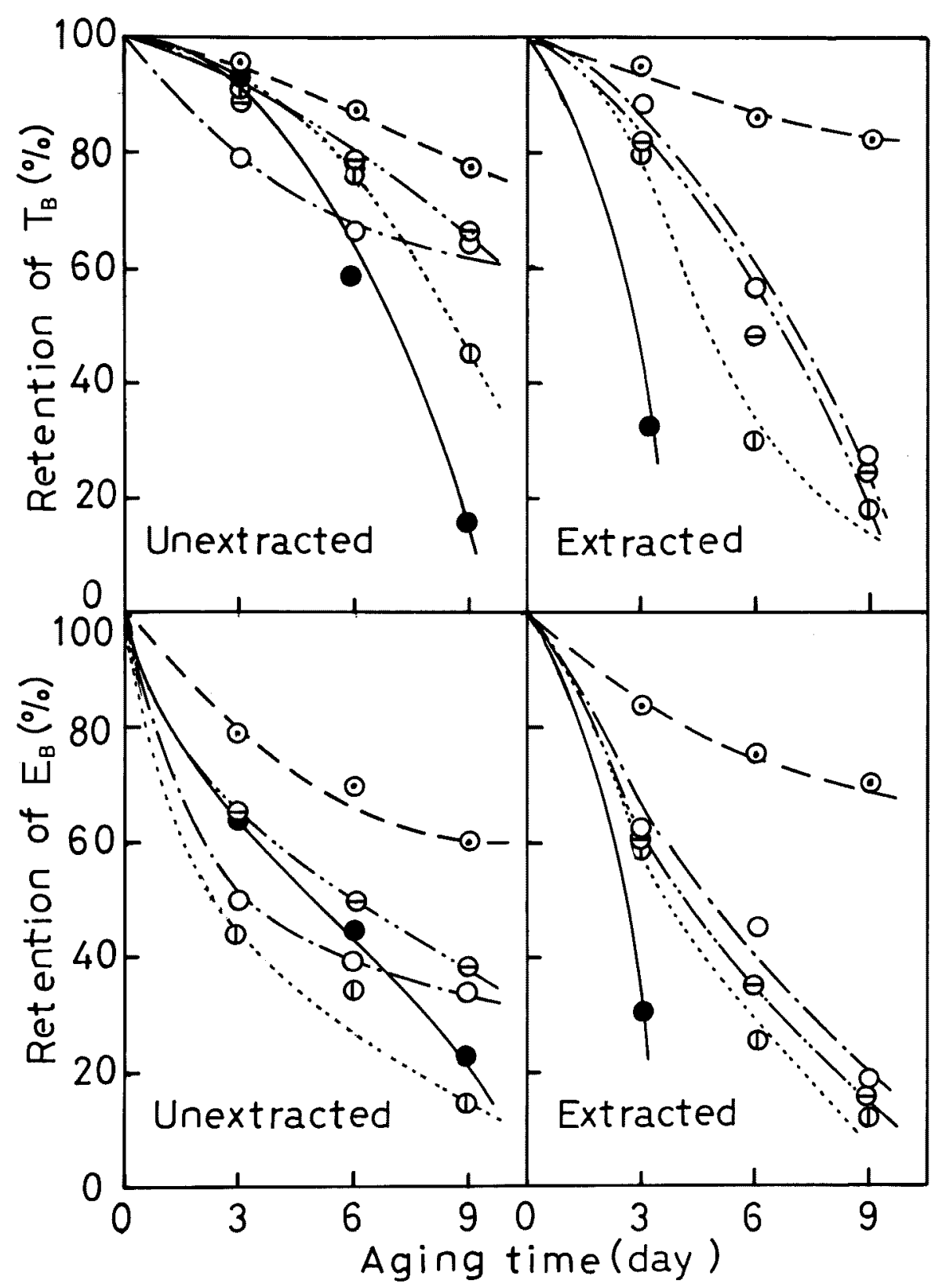

Fig. 5 Heat aging resistance of AD-3SM-cured SBR vulcanizates before and after extraction with solvents at $120^{\circ} \mathrm{C}$.

: Control, (1): No accelerator, $\odot$ : TMTM, $\ominus$ : CBS, $\bigcirc:$ MBTS

れた.

一方，比較的低温での老化条件下における加硫物の耐 熱老化性は高温下での場合と異なった㑯向を示した。す なわち, Fig. 8 と Fig. 9 に AD-3SM によるBR と IR ( 73 )

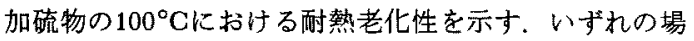
合も結合率やモ/スルフィド加硫鎖含量と耐熱老化性は 関倸なく，TMTM や CBSの上うな加硫促進剂の入ら ない加硫系が老化防止に有効であった。これは $100^{\circ} \mathrm{C}$ と 


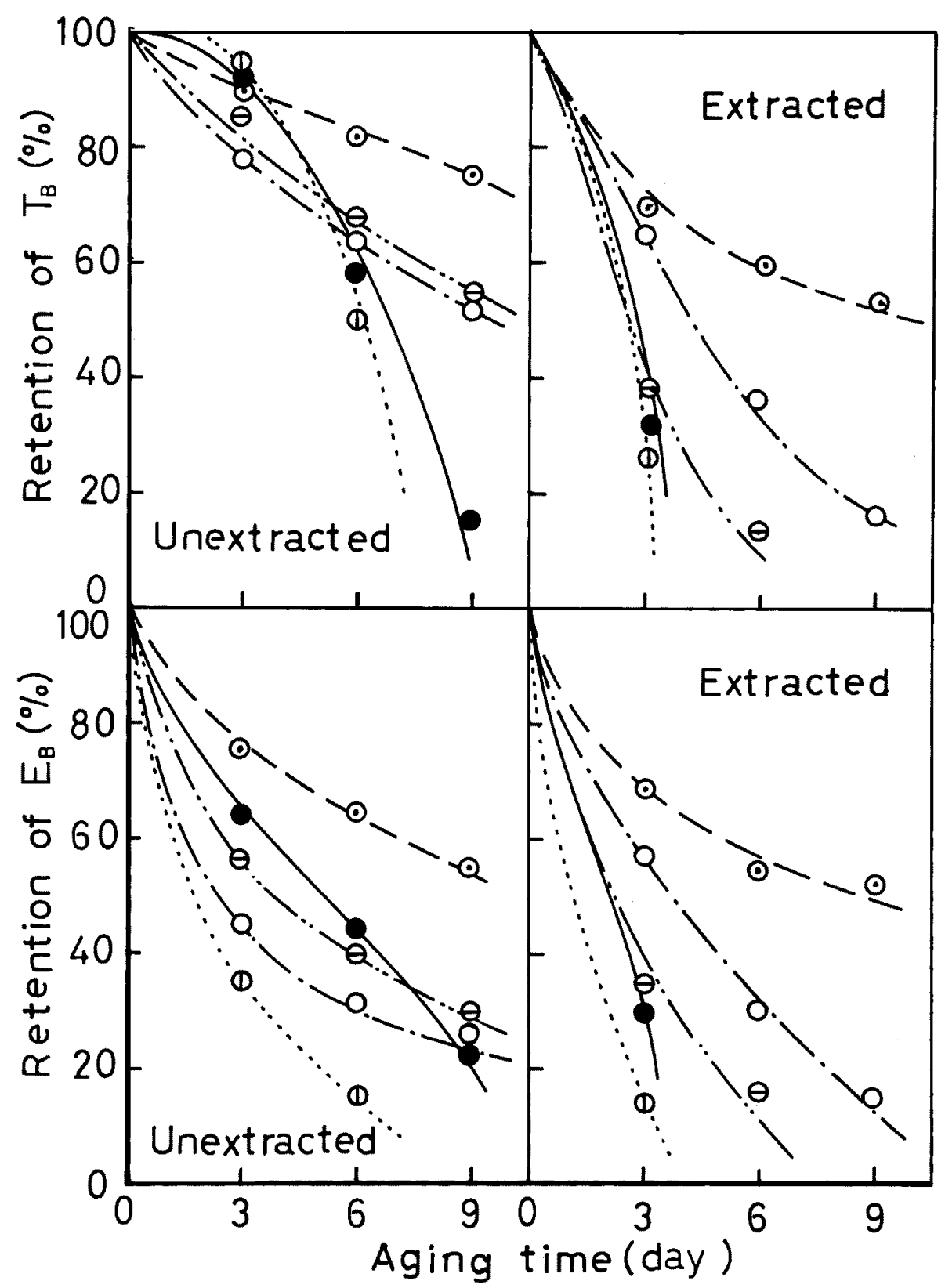

Fig. 6 Heat aging resistance of $3 \mathrm{C}-3 \mathrm{SM}$-cured SBR vulcanizates before and after extraction with solvents at $120^{\circ} \mathrm{C}$.

: Control, $\mathbb{D}$ : No accelerator, $\odot:$ TMTM, $\ominus:$ CBS, $\bigcirc:$ MBTS

いう比較的低温での老化において，抗酸化剂の揮発や加 硫鎖構造が熱老化の重要な因子でないためと考えられ Ђ.
また，加硫性抗酸化剂で加硫された EPDMはそれ自 身耐熱性に優れているため, 抗酸化性基の能力が充分発 揮されなく、コントロールと大差なかった。 


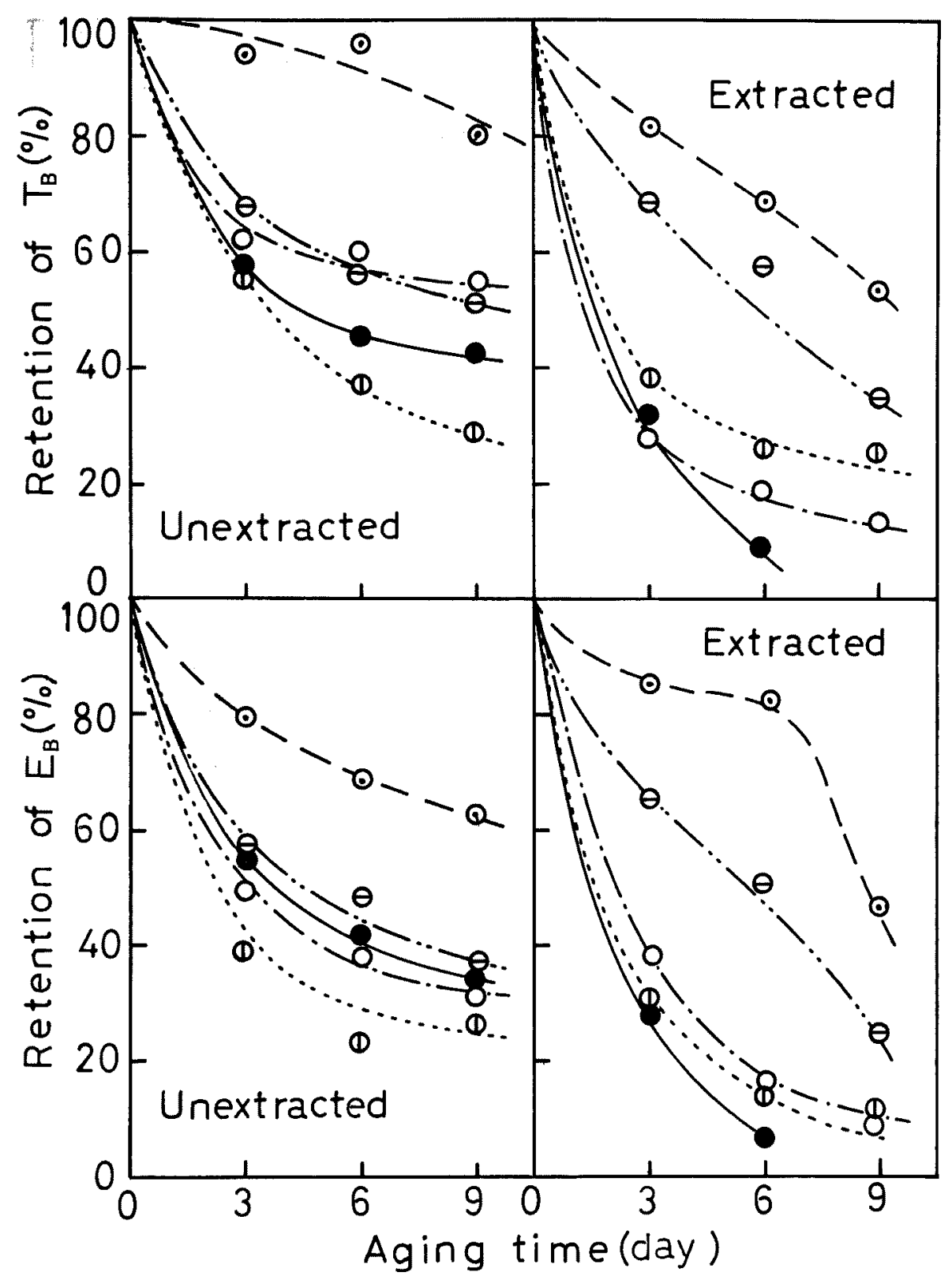

Fig. 7 Heat aging resistance of AD-3SM cured BR vulcanizates before and after extraction with solvents at $130^{\circ} \mathrm{C}$. : Control, $(\mathbb{D}:$ No accelerator, $\odot:$ TMTM, $\ominus:$ CBS, $\bigcirc:$ MBTS 


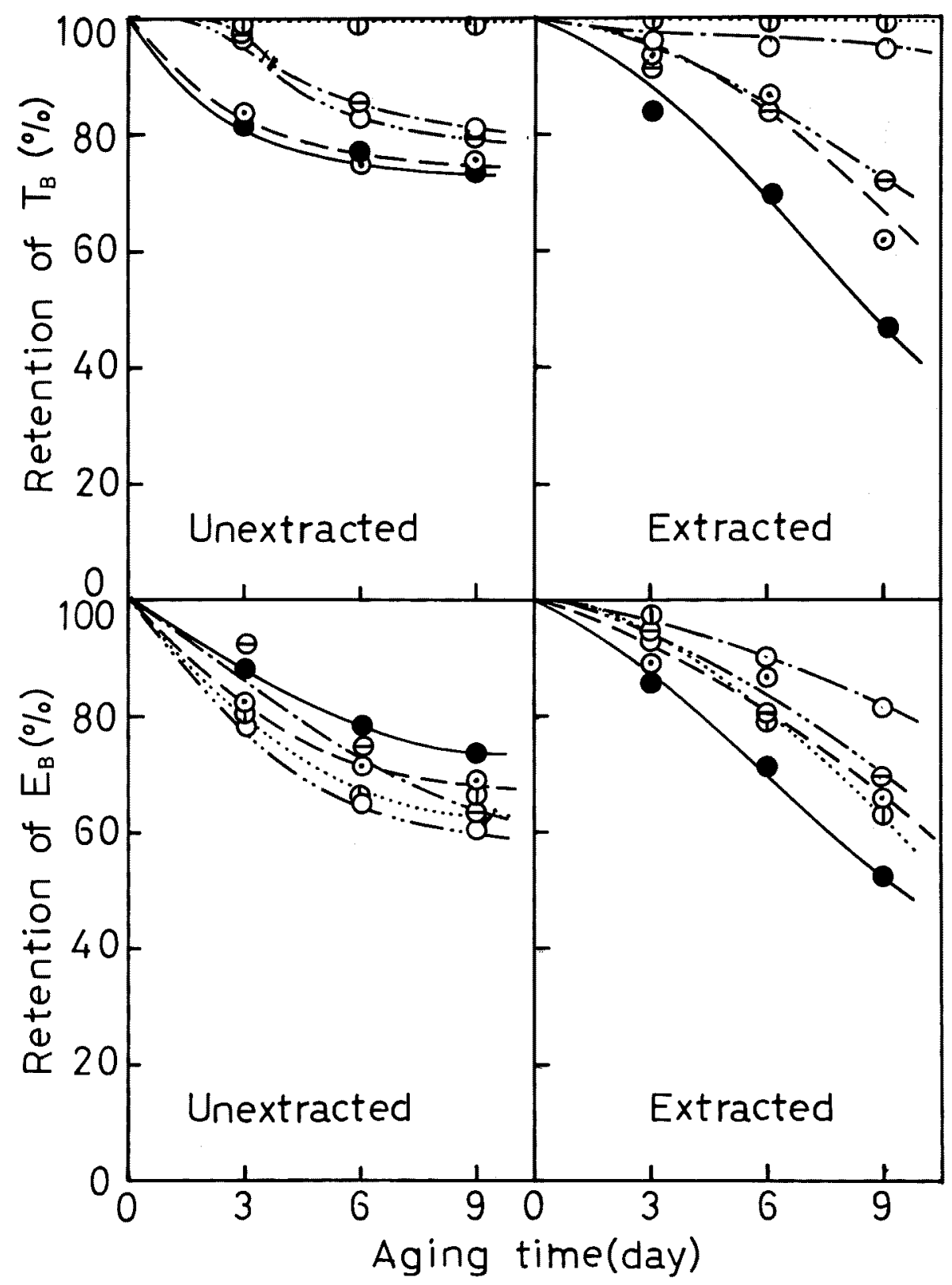

Fig. 8 Heat aging resistance of $\mathrm{AD}-3 \mathrm{SM}$ cured $\mathrm{BR}$ vulcanizates before and after extraction with solvents at $100^{\circ} \mathrm{C}$. : Control, $\mathbb{D}:$ No accelerator, $\odot:$ TMTM, $\ominus$ : CBS, $\bigcirc:$ MBTS 


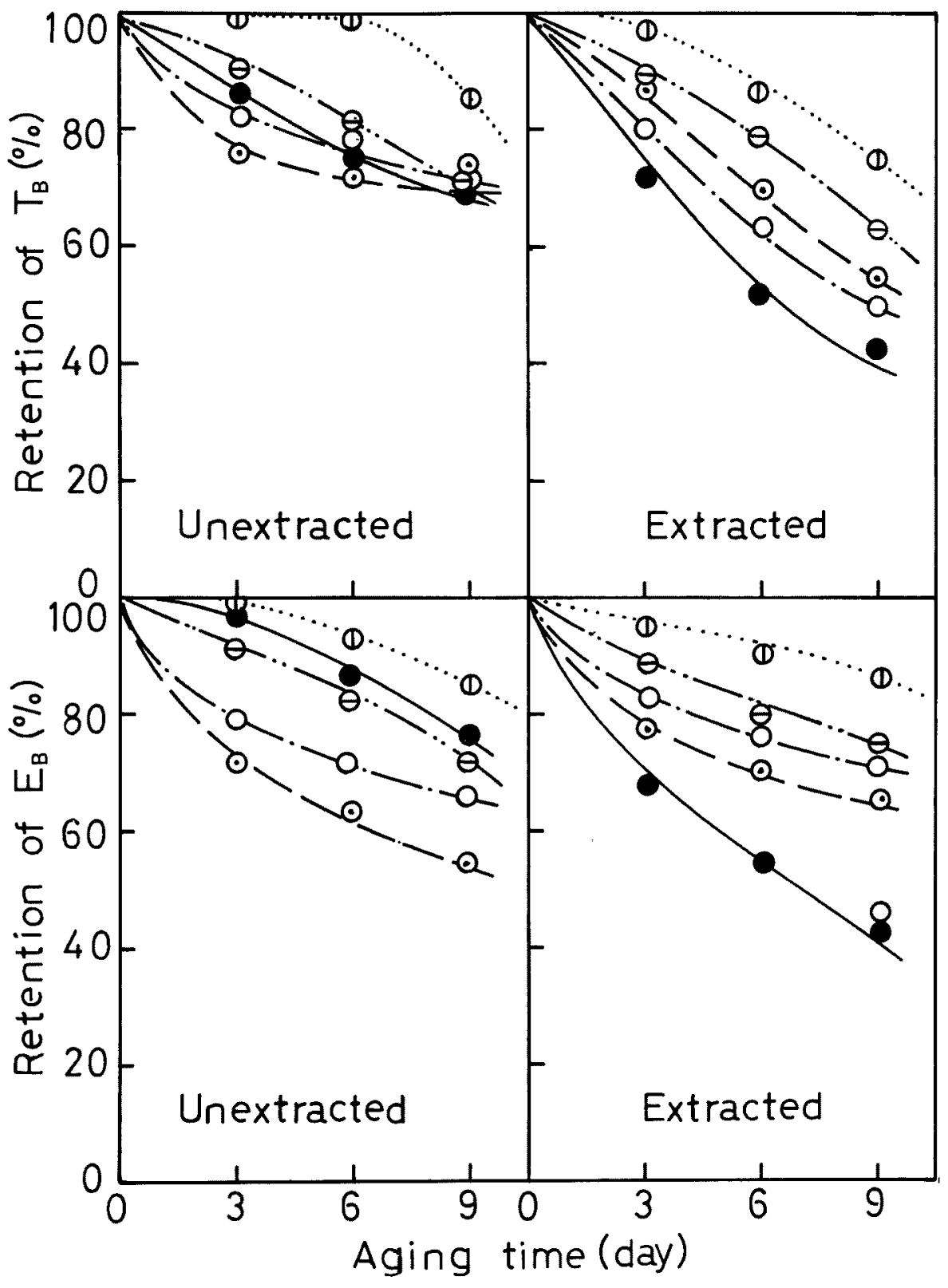

Fig. 9 Heat aging resistance of $A D-3 S M$ cured IR vulcanizates before and after extraction with solvents at $100^{\circ} \mathrm{C}$.

: Control, (D: No accelerator, $\odot$ : TMTM, $\ominus$ : CBS, $\bigcirc:$ MBTS 


\section{文献}

1）渡辺 隆：有合化誌，31，841(1973)

2) Cain, M. E., Knight, G. T., Lewis, P. M., Saville, B.: Rubber J., 105, 10 (1968)

3）山本隆造，七見達夫，関根達二，黄海升美：日ゴ 么協誌，50，548(1977)

4）中村儀郎，森 邦夫，赤石文男：日ゴム協誌， 50, 548(1977)

5) Kline, R. H., Miller, J. P.: Rubber Chem. Technol, 46, 96 (1973)

6) Meyer, G. E., Kavchok, R. W., Naples, F. J.: Rubber Chem. Technol., 45, 204 (1972)

7) Horvath, J. W., Bush, J. L., SAF Report, 770863 (1977)

8) Horvath, J. W.: Elastomers, Aug., 19 (1979)

9) Horvath, J. W.: Rubber Chem. Technol., 52, 883 (1979)
10) Morris, R. E., Gregory, J. T.: Brit. Pat., 943060

11) Kirpichev, V. P., Yakubichik, A. I., Maglysh, G. N.: Vaskomol, Soedin, Ser., A10, 2347 (1968)

12) Kay, F., Wright, W. W., Thomas, D. K.: Int. Rubber Conf., Brighton May (1972)

13）山本隆造，大原正樹，関根達二，七見達夫：日コ 么協誌，45，1099(1972)

14）中村儀郎, 森 邦夫, 長谷川健二, 齐藤孝臣：日 ت゙ム協誌，48，716(1975)

15）森 邦夫, 中村儀郎：日ゴム協誌, 57, 385 (1984).

16）森 邦夫，中村锇郎：日ゴム協誌，57，636(1984).

17）渡辺茂隆：日ゴム協誌，34，787(1961)

18) Flory. J. P.: J. Chem. Phys., 18, 108 (1950)

19) Ashikari, N., Kawashima, T.: Rubber, Chem. Technol., 42, 1245 (1969)

20）森邦夫，中村儀郎：日ゴム協誌，53， $680(1980)$

21）森 邦夫, 中村儀郎：日ゴム協誌，57，622(1984).

\title{
VULCANIZATION OF UNSATURATED RUBBERS WITH VULCANIZING ANTIOXIDANTS AND THEIR HEAT AGING RESISTANCE
}

\author{
Kunio MORI, makiko TSUNEISHI and yoshiro NAKAMURA (Department of Applied \\ Chemistry, Iwate University, Morioka, 020 Japan)
}

Evaluation of 2-antioxidant group-4,6-bis (4-morphorinyl trithio)1,3,5-triazine(Vulcanizing antioxidant) on unsaturated rubbers such as IR, BR, SBR, and EPDM has been investigated for vulcanizing properties, the \% bound of antioxidant groups, the structure of crosslinkage, and the heat resistance of vulcanizates. Vulcanizing antioxidants acted as a vulcanizing agent in the copresence of $\mathrm{ZnO}$ and stearic acid. The vulcanizing reactivity was influenced by the kind of rubbers. The copresence of accelerators such as TMTM, CBS, and MBTS was very effective to increase vulcanizating rates and crosslinking degree. The \% bound of antioxidant groups was large for BR and SBR, but small for IR and EPDM. Both CBS and MBTS were effective accelerators to increase the \% bound, and TMTM was effective one to increase the monosulfide crosslinkage contents. The combination of vulcanizing antioxidant and TMTM was found to give the vulcanizates which are effective under the conditons that contact with high temperature and solvents, in which commercial antioxidants commonly are removed, as they have both excellent $\%$ bound and monosulfide crosslinkage contents.

(Received August 1, 1983) 